\title{
NOTARY'S RESPONSIBILITY TO THE TRUTH OF DATA IN THE MAKING OF ISLAMIC BANKING CONTRACT IN INDONESIA
}

\author{
Abdul Muin \\ Wiralodra University, Indramayu \\ amuin.abdul@gmail.com
}

\begin{abstract}
Notary is a public official appointed by the government authorized to make an authentic deed as stipulated in UUJN. Authority as mentioned above includes in the making of deed or contract on Islamic Banking. A contract according to language is binding, connecting, as for the meaning of the contract by term is an association or meeting between ijab and qabul that result in law. While the definition of Islamic Banking is a bank that runs its operations based on the principles of sharia. Notary Authority as regulated in Law Number 30 Of 2004 junto Law Number 2 Of 2014 concerning Notary Position shall be based on the honesty of Notary in executing its duties and authority including within the truth of the data in the process of making the contract. The legal basis of this journal is the Qoran and Hadits, Law No. 30 of 2004, Law No. 2 of 2014 on the position of Notary, Law Number 31 Of 2008 concerning Islamic Banking and the Civil Code.
\end{abstract}

\section{Keywords: Islamic Banking, Notary's Responsibility; Creating a contract;}

\section{A. INTRODUCTION}

Notary public is a public official appointed by the government to assist the general public in terms of making existing agreements or arising in the community. The necessity of these written agreements made before a Notary is to ensure legal certainty and to fulfill a strong law of proof for the parties to the agreement. The need for a written proof requires the importance of Notary institution ${ }^{1}$. Notary is a profession and it is a noble profession (nobile offecium). In Law Number 30 Of 2004 junto Law Number 12 Of 2014 regarding the position of Notary, Article 1 Paragraph (1) states Notary is the General

1 R.Soegondo Notodisoeryo, 2012, Hukum Notariat di Indonesia, Jakarta, PT Raja Grafindo, Fouth Publishing, p.4
Officer authorized to create authentic deed and has other authority as referred to in this Act or under any other Law. ${ }^{2}$

Notary is called a noble official because the notary profession is very closely related to humanity. A Deed made by a Notary can be a legal proof of the status of a person's property, rights and duties. The mistake of a deed made by a Notary may result in the deprivation of a person's right to an obligation. Therefore, the Notary in performing his/her duties must comply with various provisions stipulated in the Notary's office law ${ }^{3}$. The notion of deed

2 Undang-undang Nomor 12 Tahun 2014 tentang Jabatan Notaris, 2015, Bandung, Fokusmedia, p.3

3 Abdul Ghofur Anshori, 2011, Lembaga Kenotariatan Indonesia, Perspektif Hukum dan Etika, Yogyakarta, UII Press, p.46 
according to A. Kahar 'deed is a writing that deliberately made to be used as evidence. If the deed is made before a Notary then the deed is said to be a notarial deed, or an authentic deed, or notarial deed. A deed is said to be authentic if it is made before an authorized official $^{4}$. The purpose of the deed is made before the competent authority is so that the deed can be used as strong evidence in case of a dispute between the parties or there is a claim from another party.

The development of globalization era is increasing rapidly today, the impact on the needs of the public against the notary and the deeds made it experience an increasingly widespread. The public now has more legal awareness in doing their legal relationships, whether it is legal relations in business, banking, and even social activities have used notary services to create authentic deeds that bind the parties in their activities.

These developments have also had a major impact, especially in the banking sector. Notary is an important element in every operational banking transaction, especially in making credit/loan guarantee deed, debt recognition, grossed deed, legalization and waarmerking, and other duties of notary which have been regulated by law and regulation.

Notary Authority also concerns on the making of contract related to Islamic Banking, either financing contract or other contract which is a product in the Islamic Banking. QS.Al-Baqarah verse 282 mentions:

"O ye who believe! When ye contract a debt for a fixed term, record it in writing...." QS.Al-Baqarah: 282.

This paragraph illustrates the importance of written evidence in every

4 A. Kahar, 2011, Notaris Dalam Praktek Hukum, Bandung, Alumni, p.64 contract, including in various matters relating to Islamic Banking, as regulated in Law Number 21 Of 2008 on Islamic Banking Article 1 paragraph (1), which states "Islamic Banking is everything that concerning Islamic Bank and Sharia Business Units, including institutions, business activities, and ways and processes in conducting business activities ". In paragraph 1 of paragraph (7), "Islamic Bank is a bank that runs its business based on sharia principles and according to its type consists of sharia commercial banks and Islamic Law (Sharia) financing".

Understanding of Islamic Bank in a simple way is a bank that carries out its activities based on the principles of sharia. Thus, its operational standard is based on sharia principles. Standards attend after system of accounting of the Islamic system $^{5}$. This paper is an attempt to analyze the efficiency of the financial. ${ }^{6}$

In the practice of Islamic Banking system issued by Bank Indonesia that the largest financing is done is murabahah. According to some books of jurisprudence, Murabahah is one of the forms of buying and selling that is amanah (trusted). This buying and selling is different from buying and selling musawwamah (bargaining). Murabahah is executed between the seller and the buyer based on the price of the goods, the original purchase price of the seller known to the buyer and the seller's profit was notified to the buyer. On the other hand, musawwamah is a transaction that is executed between the seller and

5 Perjanjian Baku Menurut Prinsip Syariah (Tinjauan Yuridis Praktek Pembiayaaan di Perbankan Syariah, accessed from Journal De Jure, State Islamic University of Maulana Malik Ibrahim Malang, at 3 January 2016.

6 Evaluating The Efficiency Of Financial Indusion, International Journal of Business, 2015, Universitas Gajah Mada Yogyakarta. 
the buyer with a price regardless of the original price of the goods. Basically, in accordance with the principle of financing does not require a guarantee submitted by the debtor customer to the bank as a creditor. However, banks in practice require assurance to obtain legal certainty that the financing provided to customers will be acceptable again.

Notary in its authority to make the deed of agreement included in making a contract in Islamic Banking must be able to ensure that all data and documents provided by the parties are really reliable data of validity. The writing of this journal is based on the legal basis which includes:

a. Al-Qur'an and Al-Hadith

b. Law Number 30 Of 2004 junto Law Number 2 Of 2014 concerning Notary Position.

c. Law Number 21 Of 2008 concerning Islamic Banking

d. Code of Civil law.

e. Bank Indonesia Regulation Number: 15/14/PBI/2013 concerning Sharia Business Unit.

f. Compilation of Islamic law.

g. Compilation of sharia economic law.

h. Articles of Association and Bylaws of the Indonesian Notary Association and the Notary Code of Conduct.

The issue that arises is how the responsibility of Notary to ensure the validity of data and documents provided by the parties in making the contract in Islamic Banking in Indonesia.

\section{B. DISCUSSION}

Notary as stipulated in Law Number 30 Of of junto Law Number 2 Of 2014, Article 1 paragraph (2) states "Notary is the general official authorized to make authentic deed and has other authority as meant in Act this or under other laws". Authority of Notary is also included in the making of contract in sharia financial institution in Indonesia.

Understanding of the contract comes from the word al'aqd which means binding, connecting, linking. Some definitions of the contract, first, the contract is an association or a meeting of consent and law which resulted in the law. The Ijab is an offer submitted by one of the parties, and qabul is the consent answer given by the contract partner in response to a first-party offer. Secondly, the contract is a two-party legal act because the contract is a meeting of consent which delivers the will of one party and the announcement of the will of the other. Third, the purpose of the contract is to produce a legal effect. More firmly again the purpose of the contract is the purpose of the intended joint and who want to be realized by the party through making the contract ${ }^{7}$. In the opinion of AlHasan "if someone gets his property then he first made transactions in the form of akad ........".

According Afzalur Rahman stated that in the principle of sharia economic contract have dunia and ukhrowi consequences because the contract is done based on Islamic law. The terms of the contract are:

a. Goods and Services must be lawful so that transactions on unlawful goods and services become null and void by sharia law

b. The price of goods and services must be clear

c. The place for delivery of goods and services should be clear as it will have an impact on transportation costs
7 Muhammad Said Is, 2015, Konsep Hukum Perbankan Syariah, Setara Press, Malang, p.76

8 E-Syariah Mahkamah Syariah Malaysia, accessed on 3 January 2016 
d. Transacted goods shall be entirely in possession. ${ }^{9}$

The meaning of the contract is also stipulated in Law Number 21 Of 2008 Article 1 paragraph (13) stating "contract is written agreement between Islamic Bank or UUS and other party which contains rights and obligations for each party in accordance with sharia principles".

In the making of a contract in a sharia financial institution, a Notary must also refer to the Notary Law, particularly in Article 15 paragraph (1) of Notary Law, which states "Notary is authorized to make an authentic deed, concerning all required deeds, agreements and stipulations by law or by any interested party to be stated in an authentic deed, guaranteeing the date of making the deed, preserving the deed, granting grosse, copies and quotations of deeds, all to the extent that the deed is not assigned or exempted to other officials or persons other which is defined by the Law ". And the code of ethics of Notary.

The code of ethics is a moral guidance, guidance on morality for a particular profession. In other words, Notary's code of ethics is guidance, principle or moral guidance of Notary either personally or as public official appointed by government in order to give public service, especially in the field of making deed. ${ }^{10}$ This code of ethics generally gives instructions to its members to practice in carrying out its profession which includes:

a. The relationship between clients and experts in the profession

$9 \quad$ Op.Cit p.77

10 Kode Etik Notaris, Ikatan Notaris Indonesia, 2015, Jakarta, p.21 b. Measurement of evaluation standards used in carrying out his profession

c. Research and publication/ discipline of the profession

d. Consultation and personal practice

e. The level of ability / competence in general

f. Personnel administration

g. Standards for research. ${ }^{11}$

In the exercise of its authority, a Notary must be responsible if the deeds are made there is a mistake or violation that is deliberately done by a Notary, this is where the importance of Notary must perform its functions and position in accordance with legislation. This spirit is contained in the nature of Rasullah SAW, namely Sidiq honest), amanah (trustworthy), tableg (provide understanding) and Fathonah (smart). In QS, Al: Ashr verse 5: meaning, Always hold the right". The Prophetic Hadith narrated by Imam Bukhori Rasulullah said "hold fast to honesty, because that honesty will lead you to the goodness and kindness that will bring you into the heaven". (HR Bukhori).

Conversely, if the mistake is made by the parties of the phases, as long as the Notary executes its authority according to the laws and regulations, the Notary concerned cannot be held accountable, since the Notary only records what is submitted by the parties to be poured into the deed. False information and proofs are the sole responsibility of the parties ${ }^{12}$. In other words that can be accounted to Notary is fraud or deception that originated

11 Suhrawandi K.Lubis, 2010, Etika Profesi Hukum, Sinar Grafika, Jakarta.p. 13

12 C.S.T Kansil dan Cristin ST Kansil, 2010, Pokokpokok Etika Profesi Hukum, Jakarta, Pradya Paramita, $4^{\text {th }}$ Publishing, p.5. 
from Notary itself. ${ }^{13}$ As long as the Notary is impartial and careful in carrying out his/her position, Notary will be more protected in performing their obligations. Similarly, as long as the Notary in exercising its authority makes in accordance with the laws and regulations, the Notary as a public official cannot be solicited from the legal side of its deed. ${ }^{14}$

However, if the deed made by the Notary is associated with the Notary Law Article 34 where the notarized deed does not have notarial legal power as an authentic deed, but only has the power of proof as a deed under the hand, ie a deed that lacks objective conditions, such as the parties or the interlocutors are not capable of acting legally, the deed becomes null and void. Notary is possible to do mistakes in carrying out their duties. ${ }^{15}$ Under such conditions a Notary may be held accountable in terms of criminal, civil or administrative law. This is in line with the prevailing principle that anyone who is harmed is entitled to make demands or claims. A lawsuit against a Notary may occur if the issuance of a Notary deed is not in accordance with the procedure so as to incur losses on the other party. The administrative sanction against Notary under Article 85 UUJN concerns the

13 Andi Mamaminanga, Pelaksanaan Pengawasan Majelis Pengawas Notaris Daerah Dalam Pelaksanaan Tugas Jabatan Notaris berdasarkan UUJN, A Thesis at Notary Department, Law Faculty of Gajah Mada University, Yogyakarta, p.32.

14 Notodisoeryo, 2011, Hukum Notarial di Indonesia (suatu penjelasan), Rajawali Press, Cet.ke2, Jakarta, p.29.

15 Endang P, Bentuk Pelanggaran Hukum Notaris di Wilayah Propinsi Banten dan Penegakan Hukumnya, Jurnal Mimbar Hukum Univesitas Gajah Mada Yogyakarta,accessed on 3 January 2016 provisions as meant in Article 7, Article 15 paragraph (1,2 and 3), Article 16 paragraph (1) letter $b, c, f, g, i, j$ and Article 20, Article 27, Article 32, Article 37, Article 54, Article 58, Article 63, may be subject to the following sanctions:

a. Verbal reprimands

b. Written warning

c. Temporary stop

d. Dismissal with respect, or

e. Dismissal not with respect

In accordance with its authority in making the deed, the notary is entitled to make all deeds required by the parties to the extent that the authority to make such deed is not excluded to other parties (openbaar ambtenaar), eg, the making of a marriage certificate by the Office of Religious Affairs or birth certificate issued by the Notes Office Civil. When it is associated with the making of a deed between the bank and the borrower's customer, the notary is entitled and authorized to make all deeds requested by the parties. On the other hand, the party in the granting of the debt with the guarantee, where the guarantee submitted by the debtor's customer is the land, the guaranteed land is the certified land. This is because there is no official guarantee agency for land that has not been certified. Based on this matter then arises the problem, where sometimes borrowers borrow money borrowed by the guarantee of land that has not been certified. Typically, state banks do not accept the land that has not yet been certified to be pledged as collateral, unless the guarantee that the land has not been certified is made a power of attorney to take care of making the certificate of right by the bank, and continued with the Letter. 


\section{Form of responsibility of a Notary in terms of Civil Law}

As outlined above, the deeds made by Notaries relating to civil affairs concern on the engagement made by two or more parties, although they may be made unilaterally (of merely reinforcing). The nature and principles embodied in the law of engagement, in particular the engagement arising out of the treaty, that the Law is only possible and may be amended or replaced or declared invalid, only by those who make it, in other words the agreement of both parties as set forth in a deed authentic will bind both parties as binding the Act.

That the accountability of a person's actions is usually practically meaningless when the person commits acts that are not permitted by law and most of these deeds are an act in the Civil Code called an act against the law. ${ }^{16}$ This Agreement shall not be withdrawn other than the agreement of both parties which makes it (Article 1138 Civil Code). Therefore, an agreement or agreement, which has the power as a law, can only be annulled by both parties making a deed or a covenant. This applies also to the deed or contract related to the sharia financial institution. In other words, if certain parties with Notary make changes in the act or contract, then the party who feels aggrieved may claim compensation to the Notary. Article UUJN Article 84 states that it can be a reason for the suffering party to demand compensation of costs, compensation, and interest to the Notary of Compensation on the basis of unlawful acts within the decisive Criminal Code of Article 1365. Any offense that brings harm to the other party requires that due to the wrong to issue the

16 Downloaded from: http://wardanirizki.blog spot.co.id/2013/10/tanggung-jawab-notaris ditinjau-dari.html accessed at 12 February 2018. loss, to compensate for such loss. If we consider in this Article contained the following elements:

a. Unlawful acts

b. There must be an error

c. There should be losses incurred

d. There is a causal relationship between deeds and losses

Unlawful acts are defined as acting or not acting in violation of the rights of others, or contrary to the legal obligations of the person who is acting on their own, or in contravention of morality or caution as appropriate in the passage of the public to the self or to the goods of others. ${ }^{17}$

\section{Forms of responsibility of Notary in terms of criminal law}

The responsibility of a notary in a criminal law on a deed or contract made in it is not regulated in the UUJN, but the responsibility of a Notary is criminal law is known if the Notary commits a crime. As outlined above, the Notary in the case of the validity of the data provided and the information submitted to the Notary is wholly the responsibility of the parties facing. Because the Notary only records what the parties say to be stated in the deed. The false notes given by the parties to the Notary are the responsibility of the parties. The above mentioned deeds include a contract made by a Notary in a sharia financial institution in Indonesia.

Law Number 30 Of 2004 regarding Position of Notary (UUJN) does not regulate the criminal provisions. UUJN only regulates sanctions for violations committed by a notary to the UUJN, such sanctions may be sanctions against the deed he made and the notary. Sanctions against the deed he made make the deed made by the notary down from the

17 Ridwan Syahroni, 2010, Seluk beluk dan asasasas hukum perdata, Bandung, Alumni, p.264. 
authentic deed or become deed under the hand, while for the notary is given sanctions ranging from reprimand to lead to dismissal with disrespect.

Criminal conduct is an act that is prohibited by a rule of law, if a violation of the prohibition will be followed by sanctions in the form of certain criminal. In carrying out his position as a notary then the intended criminal is a criminal committed by a notary in his capacity as a public official authorized to make an authentic deed held by UUJN, not the personal or individual capacity of the notary as a legal subject.

\section{Forms of responsibility of Notary of administrative law}

In view of the description of Article 1 Sub-Article 1 of Law Number 2 of 2014 concerning the Notary's Office there is a sentence "all during the making of a deed by a general rule not also assigned or excluded to officials or others". The sentence only excludes that the deed if the Law otherwise requires, then the Notary does not have the authority to make the deed. This provision shows that as long as the deed made by the Notary is made in accordance with that required by a general rule or by an interested party desirable to be declared in a deed. Notary then cannot be held accountable for the deed he made. But as an ordinary person who cannot avoid mistake in making the deed, then the Notary can get sanction, one of the sanctions is administrative sanction. Regarding administrative sanction as regulated in Article 85 UUJN concerning the provisions as meant in Article 7, Article 15 paragraph (1,2, and 3), Article 16 paragraph (1) letter $d$, Article 16 paragraph (1) letter $h$, Article 16 paragraph (1) letter $j$, Article 16 paragraph (1) k, Article 17, Article 17, Article 20, Article 27, Article 32, Article 37, Article 54 and Article 63 Subject to sanctions in the form of:

1. Verbal reprimands

2. Written warning

3. Temporary stop

4. Dismissal with respect, or

5. Dismissal not with respect.

\section{CONSLUSION}

Islamic Banking includes, sharia commercial banks, sharia business units and sharia financing banks. In principle, sanctions that can be given to Notaries as public officials can be categorized as administrative sanctions, civil sanctions and criminal sanctions. Duties and responsibilities of a Notary as a public official authorized to create deeds or contracts and or agreements which fall under its authority and cannot be held liable in relation to information and data and documents provided to Notaries, since the task of Notary only records the statements of the parties facing as stipulated in deed or akad, including akad in sharia sacrifice in Indonesia. 


\section{BIBLIOGRAPHY}

\section{- Books}

A.Kahar, 2011, Notaris dalam Praktek Hukum, Alumni, Bandung.

Abdul Ghofur Ansori, 2011, Lembaga Kenotariatan Indonesia, UII Press, Yogyakarta.

Anggaran dasar dan Anggaran Rumah tangga dan Kode Etik Notaris, 2015, Indonersiar Notary Asosiation, Jakarta.

Christine ST. Kansil, C.S.T Kansil, 2013, Pokok-pokok Etika Profesi Hukum, Pradyi Paramita, Jakarta.

Notodisoeryo, 2011, Hukum Notarial di Indonesia, Jakarta, Rajawali Press.

R.Soegondo, 2010, Notodisoeryo, Hukum Notariat di Indoneisa, Jakarta, PT Rajc Grafindo.

Riduan Syahroni, 2010, Seluk Beluk dan Asas-asas Hukum Perdata, Bandung, Alumni.

Suhrawandi K.Lubis, 2010, Etika Profesi Hukum, Jakarta, Sinar Grafika.

\section{- Journal}

Internasional Journal, e-Syariah Mahkamah Syariah Malaysia.

Internasional Journal, 2015, International Journal Of Business Gajah Mada University Yogyakarta.

National Journal, 2015, Journal De Jure, State Islamic University of Maulana Malil Ibrahim, Malang.

National Journal, 2015, Mimbar Hukum, Gajah Mada University, Yogyakarta.

\section{- Law}

Act. No. 2 of 2014 On Notary Official, 2015, Bandung. Fokusmedia.

Act. No. 20 of 2008 On Islamic Banking, 2012, Bandung, Fokusmedia. 